\title{
Forensic entomology research in Egypt: a review article
}

\author{
Ashraf Mashaly $^{1 *}$ (D) and Abdelwahab Ibrahim²
}

\begin{abstract}
Background: Forensic entomology (FE) is widely considered as an important field of forensic science, particularly in the field of estimating postmortem intervals, which has advanced considerably across the world.

Main body: Researchers used necrophagous insects in twelve Egyptian governorates to look into the variables that impact insect succession and the growth of juvenile stages from infesting animal models and humans, draw toxicological conclusions, and identify insect species using morphological and molecular-based approaches. The study includes analyses of insect abundance and dispersion, along with biochemical and electrophysiological experiments. Comparable data from other Egyptian governorates, on the other side, is currently unavailable. Aspects of FE are also missing, which might be addressed in a future research project.

Conclusion: This review aims to provide an outline of FE in Egypt, other than to assist existing researchers in identifying research needs and recruiting new researchers into the field by highlighting significant forensic insects that might be employed in criminal prosecutions.
\end{abstract}

Keywords: Corpses, Entomotoxicology, Insect succession, Necrophagous, Postmortem interval

\section{Background}

In forensic entomology (FE), insects are studied for legal purposes, such as in a court of law (Catts \& Goff, 1992), to assist in estimating the postmortem interval (PMI) (Campobasso and Introna, 2001), in cases where corpses are transported from one location to another, and the method and cause of death (Sukontason et al., 2007). Estimating the PMI predicted on the premise that insects land on the corpse soon after death is critical to employing insects as a resource in court proceedings, according to Amendt et al. (2007). As a corpse decomposes, flies are drawn to the odors produced by gases and biological fluids leaking from natural body holes, as well as blood escaping from wounds, generating a variety of microhabitats, each of which attracts its own species of insects (Lord \& Rodriguez, 1989). By examining the

\footnotetext{
*Correspondence: mashaly69@gmail.com

1 Department of Zoology, Faculty of Science, Minia University, El

Minia 61519, Egypt

Full list of author information is available at the end of the article
}

development and/or succession patterns (SPs) of insects found on human remains, forensic entomologists can estimate the PMI (Goff, 1993). Many factors were found to impact on the SPs such as season, location, and microclimate (Lord \& Rodriguez, 1989; Byrd \& Sutton, 2020). Another application of FE is the detection of chemicals in decaying tissues (Nuorteva and Nuorteva, 1982). Furthermore, according to Zhu et al. (2007), entomology is used in criminal investigations in several countries.

Insect identification is one of the most significant techniques in FE. Because only deceased specimens are usually available from the scene, and they are typically in poor condition, morphological identification was mostly utilized. So, DNA methods were utilized to identify insects to solve this problem (Catts \& Goff, 1992). Insect species have varying temperature and developmental needs based on their biogeographic zone; therefore, development studies are important (Tabor et al., 2005). Furthermore, the species composition and SPs of a deceased cadaver are affected by the geographical location and season (Anderson 2001, Grassberger \& Frank, 
2004; Mashaly et al., 2017). Also, when calculating the time before death in another location, evidence from one area should be taken with caution.

According to Zhu et al. (2007), entomology is used in crime investigation in several nations, including murder and other high-profile crimes. The present research investigates FE research in Egypt and the possibility of using entomology in criminal matters.

\section{Collecting data}

Using Google Scholar, a past working of the current published literature on various aspects of $\mathrm{FE}$ and its legal implications in Egypt was conducted. Additionally, numerous related Web pages were accessed. To find information in the literature, the following search keywords were employed individually and in combination: "Forensic Entomology," "Insect succession," " DNA Barcoding in Insects," "Insect development," "Entomotoxicology," and "Egypt." When writing this review paper, publications regarding insects that did not have a forensic focus were excluded. This study included and examined 55 peer-reviewed academic publications.

\section{Study locations}

Egypt is a transcontinental country that extends from Africa's northeastern corner to Asia's southwest corner, spanning the Sinai Peninsula. There are also 27 governorates in Egypt (Fig. 1). Egypt is located between 22 and $36^{\circ} 31^{\circ}$ north latitude, with the cancer's orbit crossing over Aswan and lying between 24 and $37^{\circ}$ east of Greenwich. Egypt has an arid desert environment throughout, except for a tiny stretch of Mediterranean shoreline. Days in Egypt are often warm to hot, and evenings are chilly. It only has two seasons: a moderate winter (November to April) and a warm summer (May to October). During the summer, temperatures throughout almost the whole country reach $30^{\circ} \mathrm{C}\left(86^{\circ} \mathrm{F}\right)$ during the day and (much) higher at night. Temperatures as high as $40^{\circ} \mathrm{C}\left(104^{\circ} \mathrm{F}\right)$ in the shade are not uncommon in the season. The annual precipitation in most parts of Egypt is less than $80 \mathrm{~mm}$ (3.14 inches). Even though most of the rain falls along the coast, the wettest area (around Alexandria) only receives about $200 \mathrm{~mm}$ (7.87 inches) of rain each year.

As far as we know from the available literature, FE studies in Egypt began in 1991. There have been 55

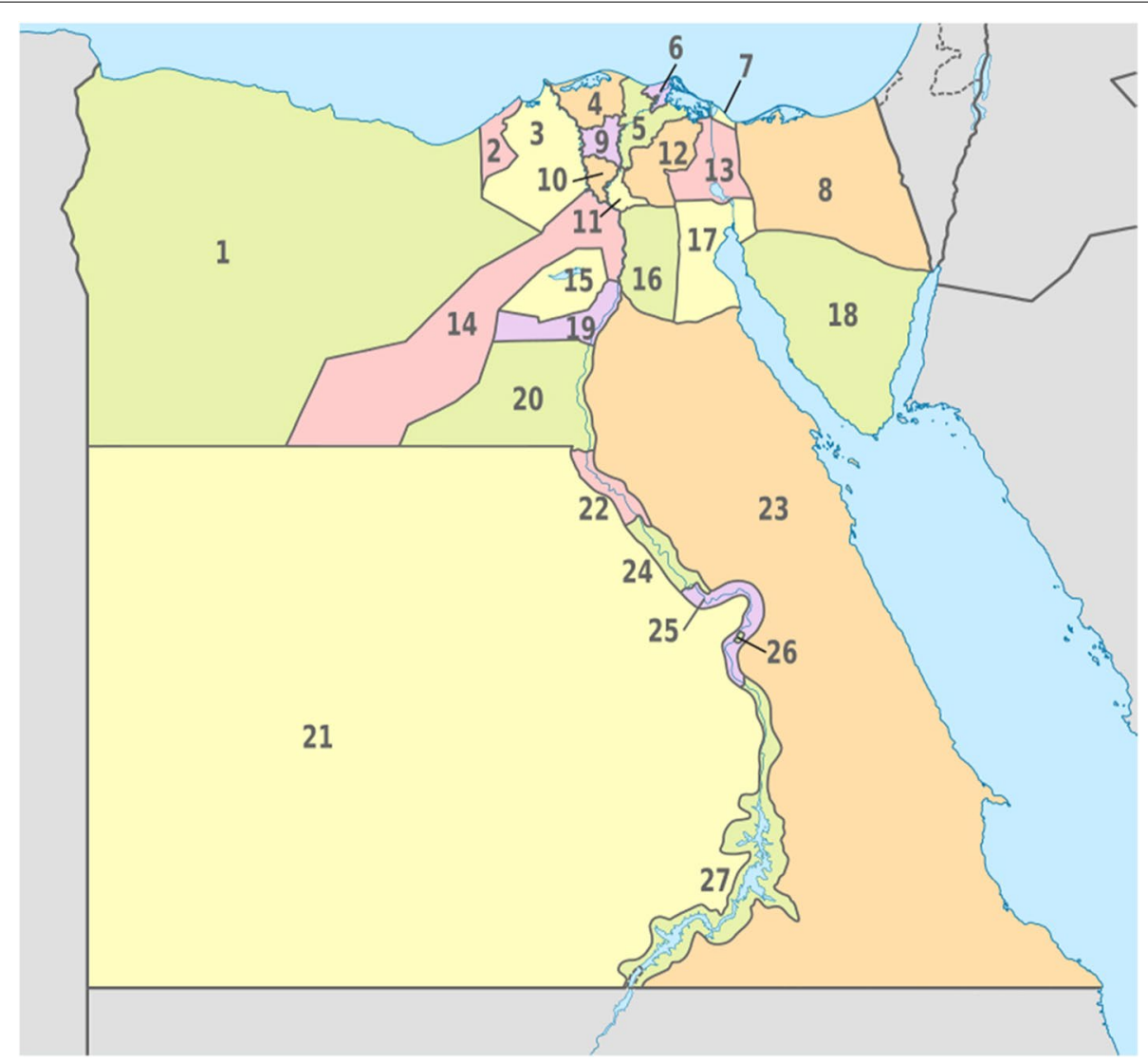

Fig. 1 A map of Egypt's governorates showing where research was conducted, as well as the most frequent species found in each governorate: 1 . Matrouh, 2. Alexandria, 9. Gharbia, 11. Qalyubia, 12. Sharqia, 13. Ismailia, 14. Giza, 16. Cairo, 17. Suez, 22. Asyut, 25. Qena 
studies, all of which were done in " 12 " varied governorates (Fig. 1). Alexandria and Cairo had the most studies (16 each), followed by El-Qalyubiya with 4 studies, Assiut and Suez with 3 studies each, and Giza, Fayoum, Sharqia, and Ismailia with two studies each. Gharbia, Qena, and Matrouh each have one study. In addition, two investigations were conducted in different locations (Table 1).Fouda et al.

\section{Main text}

In Egypt, seven disciplines of FE research were undertaken: insect succession (23 studies), developmental studies (9), entomotoxicology (8), insect identification (9), electrophysiological study (2), biochemical study (1), and a human case study (3). Throughout these studies, Hegazi et al. (1991) conducted the first research in Matrouh (Western desert), followed by EL-Kady et al. (1994a, b) in Alexandria. El-Shazly et al. (1995) conducted research in Giza, and AbouZied et al. (2003) began their research in Cairo. The research continued in further locations, with the most recent being handled in Alexandria (El-Samad et al., 2020), Cairo (Abd El-Gawad et al., 2020), Giza (AbouZied et al., 2020), and Sharqia (Farag et al., 2021).

\section{Carcass decomposition, insect distribution, and succession studies}

Over time, the carcass decomposed into well-known decaying stages (Henssge et al., 1995), drawing flies, beetles, ants, and a range of more arthropods (Catts \& Haskell, 1990). Temperature, humidity, clothing, burning, and food availability are all elements that impact carrion decay and SPs in each location (Campobasso et al., 2001). In addition, the PMI may also be estimated by examining arthropod SPs and stages of body decay (Smith 1986; Voss et al., 2011; Morris \& Dadour, 2015). In Egypt, research on corpse decomposition and SPs were carried out in eleven governorates that may represent various settings.

\section{Matrouh}

In the Western desert of Matrouh governorate, Hegazi et al. (1991) studied the monthly SPs of insects on the flesh of a mature snail and a small carp in two habitats (above and below the ground). Nine insect families were discovered, with 19 insect species belonging to the three orders of flies, beetles, and ants. Insects appeared to like fish baits somewhat more than snail baits. During the study period, flies were the most frequent insects on both baits, with the Calliphorid family being the most common. Diptera seemed to consume aboveground carrion, whereas Histerids and Dermestids beetles were found both above and below the ground surface. According to this study, the SPs of insects differed dependent on the carcass type and habitat.

\section{Alexandria}

Rabbits were employed as experimental animals in six studies. Seasonal fluctuations, as well as the reasons of mortality and the stage of decomposition (El-Kady et al., 1994a, EL-Kady et al., 1994b), have been found to influence the decaying process and SPs (Tantawi et al., 1996). Tantawi et al. (1998) also looked at the fly larvae SPs on rabbit carcasses subjected at the same time and in the same place from three groups, blowflies, flesh flies, and house flies. The other two experiments looked at the impacts of propoxur (Abdel Ghaffar et al., 2008) and amitriptyline (Abdel Ghaffar et al., 2008). (El-Samad \& Youssef, 2016). The presence of such chemicals impacted the duration of decay stages, SPs, and the rate at which their immature stages grew, according to the researchers. Researchers in Alexandria observed that insect SPs were impacted by mortality reasons, seasonal changes, and the existence of chemicals.

\section{Suez}

Gabre (2002) and Gabre and Abou Zied (2003) conducted a seasonal field research using four bait traps (fish, bovine-lung, grapes, and molasses) to characterize the abundance levels, pattern, and sex ratio of carrion flies. The most abundant flies found during the trial were Lucilia cuprina Wiedemann, Chrysomya megacephala Fabricius, and Musca domestica Linnaeus. Furthermore, the almost identical number of male and female flies captured on grape and molasses baits might represent the real male-female population balance. Female flies were also found in far greater numbers on fish and bovine-lung baits than on grape or molasses baits. Lastly, the number, distribution, and sex ratio of carrion flies were all impacted by the bait type, according to the two studies in Suez.

\section{El-Qalyubiya}

In the Governorate, two studies were included. Abd EL-Bar and Sawaby (2011) explored the role of pirimiphos-methyl, an organophosphate pesticide, on the process of decay and insect attractiveness. They observed that whereas the bodies of control rabbits decomposed quickly, the carcasses of treated rabbits did not, even after 40 days. The same group of insects invaded the guinea pig and rabbit carcasses, with Chrysomya albiceps Wiedemann being the first to arrive. On the treated carcasses, there were less blowfly larvae, which might explain the unusual decaying delay. Formicidae were noticed in all dead bodies, particularly in the early stages 
Table 1 Number of published papers from Egypt per governorate

\begin{tabular}{|c|c|c|c|c|}
\hline Governorate & $\begin{array}{l}\text { Number of } \\
\text { articles }\end{array}$ & Study field & Animal model & Reference \\
\hline \multirow[t]{8}{*}{ Alexandria } & \multirow[t]{8}{*}{16} & $\begin{array}{l}\text { SPs } \\
\text { SPs }\end{array}$ & \multirow{8}{*}{$\begin{array}{l}\text { Rabbit } \\
\text { Rabbit } \\
\text { Rabbit } \\
\text { Rabbit } \\
\text { Rabbit } \\
\text { Rabbit } \\
\text { Rabbit } \\
\text { Rabbit } \\
\text { Rabbit } \\
\text { Rabbit } \\
\text { Rabbit } \\
\text { Rabbit } \\
\text { Rabbit } \\
\text { Rabbit } \\
\text { Human } \\
\text { Rabbit }\end{array}$} & $\begin{array}{l}\text { EL-Kady et al. (1994a) } \\
\text { EL-Kady et al. (1994b) }\end{array}$ \\
\hline & & $\begin{array}{l}\text { SPs } \\
\text { SPs } \\
\text { Insect identification } \\
\text { Entomotoxicology } \\
\text { Insect development } \\
\text { Insect development }\end{array}$ & & $\begin{array}{l}\text { Tantawi et al. (1996) } \\
\text { Tantawi et al. (1998) } \\
\text { Tantawi and El-Kady (1997) } \\
\text { Tantawi et al. (2001) } \\
\text { Kheirallah et al. (2006) } \\
\text { Kheirallah et al. (2007) }\end{array}$ \\
\hline & & $\begin{array}{l}\text { SPs } \\
\text { Electrophysiology }\end{array}$ & & $\begin{array}{l}\text { Abdel EL-Ghaffar et al. (2008) } \\
\text { Refai et al. (2009) }\end{array}$ \\
\hline & & Entomotoxicology & & El-Samad et al. (2011) \\
\hline & & Electrophysiology & & Abdel Ghaffar et al. (2012) \\
\hline & & SPS & & El-Samad and Youssef (2016) \\
\hline & & Insect identification & & Abdel Ghaffar et al. (2018) \\
\hline & & $\begin{array}{l}\text { Human cases } \\
\text { Entomotoxicology }\end{array}$ & & $\begin{array}{l}\text { Tantawi et al. (2018) } \\
\text { El-Samad et al. (2020) }\end{array}$ \\
\hline \multirow[t]{15}{*}{ Cairo } & \multirow[t]{15}{*}{16} & Insect development & - & Gabre et al. (2005) \\
\hline & & Biochemical studies & Rabbit & Sawaby et al. (2009) \\
\hline & & SPS & Rabbit and dog & Zeariya et al. (2015) \\
\hline & & SPS & Rabbit and guinea pig & Abd EL-Bar et al. (2016) \\
\hline & & Insect identification & - & Sawaby et al. (2016) \\
\hline & & Insect identification & - & Elleboudy et al. (2016) \\
\hline & & Entomotoxicology & - & Fouda et al. (2017a) \\
\hline & & Entomotoxicology & - & Fouda et al. (2017b) \\
\hline & & Insect development & Rabbits & Abd El-Gawad et al. (2018) \\
\hline & & Insect identification & Rabbit and guinea pig & Sawaby et al. (2018) \\
\hline & & $\begin{array}{l}\text { SPs } \\
\text { Entomotoxicology }\end{array}$ & $\begin{array}{l}\text { Rabbit and dog } \\
\text { Rabbits }\end{array}$ & $\begin{array}{l}\text { Zeariya et al. (2018) } \\
\text { Bakr et al. (2018) }\end{array}$ \\
\hline & & SPs & Rabbits & Abd El-Gawad et al. (2019) \\
\hline & & SPs & Rabbit and dog & Zeariya and Kabadaia (2019a, b) \\
\hline & & SPs & Dog & Zeariya and Kabadaia (2019a, b) \\
\hline & & Entomotoxicology & Rabbit & Abd El-Gawad et al. (2020) \\
\hline \multirow[t]{3}{*}{ El-Qalyubiya } & \multirow[t]{3}{*}{4} & SPS & Rabbit & Abd EL-Bar and Sawaby (2011) \\
\hline & & $\begin{array}{l}\text { SPs } \\
\text { Insect identification }\end{array}$ & $\begin{array}{l}\text { Guinea pig } \\
\text { Guinea pig }\end{array}$ & $\begin{array}{l}\text { Ibrahim et al. (2013) } \\
\text { El-Hefnawy (2013) }\end{array}$ \\
\hline & & Insect development & - & Ibrahim et al. (2014) \\
\hline Assiut & 3 & $\begin{array}{l}\text { Human cases } \\
\text { Insect development } \\
\text { SPs }\end{array}$ & $\begin{array}{l}\text { Human } \\
- \\
\text { Rat }\end{array}$ & $\begin{array}{l}\text { Galal et al. (2009) } \\
\text { Elshehaby et al. (2016) } \\
\text { Abd El-Aziz and El Shehaby (2019) }\end{array}$ \\
\hline Suez & 3 & $\begin{array}{l}\text { SPs } \\
\text { SPs } \\
\text { Insect development }\end{array}$ & $\begin{array}{l}- \\
- \\
-\end{array}$ & $\begin{array}{l}\text { Gabre R. M. (2002) } \\
\text { Gabre and Abou Zied (2003) } \\
\text { Abou Zied et al. (2003) }\end{array}$ \\
\hline Fayoum & 2 & $\begin{array}{l}\text { SPs } \\
\text { Entomotoxicology }\end{array}$ & Rats & $\begin{array}{l}\text { AbouZied EM (2016) } \\
\text { Tahoun and Abouzied (2017) }\end{array}$ \\
\hline \multirow[t]{2}{*}{ Giza } & \multirow[t]{2}{*}{2} & Insect development & - & El-Shazly et al. (1995) \\
\hline & & SPs & Rabbit & Abouzied et al. (2020) \\
\hline \multirow[t]{2}{*}{ Ismailia } & \multirow[t]{2}{*}{2} & SPs & Rabbit and rats & Aly et al. (2013) \\
\hline & & Insect identification & - & Aly (2014) \\
\hline Sharqia & 2 & $\begin{array}{l}\text { Insect development } \\
\text { SPs }\end{array}$ & $\begin{array}{l}\text { Rabbit } \\
\text { Rat }\end{array}$ & $\begin{array}{l}\text { Rashed et al. (2015) } \\
\text { Farag et al. (2021) }\end{array}$ \\
\hline Matrouh & 1 & SPS & Mature snail flesh and a small carp & Hegazi et al. (1991) \\
\hline Gharbia & 1 & Human cases & Human & El-Mehy et al. (2015) \\
\hline Qena & 1 & SPs & Rabbit & Aly et al. (2017) \\
\hline
\end{tabular}


Table 1 (continued)

\begin{tabular}{lllll}
\hline Governorate & $\begin{array}{l}\text { Number of } \\
\text { articles }\end{array}$ & Study field & Animal model & Reference \\
\hline Different locations & 2 & Insect identification & Fish & Salem et al. (2015) \\
& & - & El-Hefnawy et al. (2020) \\
\hline
\end{tabular}

of decay. Ibrahim et al. (2013) discovered that guinea pig corpses decayed quickly in the fall and summer, that insect attraction followed a predictable seasonal pattern, and that the insect colony grew in richness as the decay continued. Seasonal and decaying stage differences, or the existence of chemicals, all influence the insect exposed to carcasses, according to the two experiments in El-Qalyubiya.

\section{Ismailia}

Aly et al. (2013) conducted a research in Ismailia, where they examined SPs and identified attracted species on rabbit and rat remains during the summer. Four fly families, two beetle families, and one ant species (Monomorium minimum Buckley) were among the insects gathered. Finally, the research showed that the decay rate and the number of visitor species varied depending on the decay stage.

\section{Cairo}

In Cairo, six studies were conducted, four of which looked at the effects of seasonal and habitat change and two of which looked at the effects of chemicals. Using rabbits and dogs as animal models, Zeariy et al. (2015, 2018) and Zeariya and Kabadaia (2019a, b) examined the different influences of carcass decomposing stages, carcass type, and habitats (indoor and outdoor) on insect diversity and SPs. According to the studies, the blowfly, Ch. albiceps, was the first fly driven to the initial days of decaying. Likewise, the insect variety on the two carcasses looked to be rising outdoors and decreasing indoors, with larger numbers seen on dog carcasses than rabbit carcasses. Also impacted by the decaying stage are the amount and variety of insects. In particular, the warmer seasons had the shortest larval and pupal lengths, whereas the cold seasons saw the longest larval and pupal lengths.

Zinc phosphide-intoxicated (Abd EL-Bar et al., 2016) and warfarin (Abd El-Gawad et al., 2019) chemicals have been studied for their influence on SPs and decomposing processes. Control carrions decomposed quicker than treated corpses, according to Abd EL-Bar et al. (2016), whereas treated carcasses decomposed faster than controls, according to Abd El-Gawad et al. (2019). In addition, control carcasses attracted more insects than zinc phosphide-intoxicated treated carcasses, but warfarin carcasses attracted much more insects than control bodies. Furthermore, Abd ElGawad et al. (2019) remarked that the rabbit fur color influences insect attractiveness, with black rabbit remains attracting more adults than other colors.

According to the studies conducted in Cairo, changes in carcass type and habitat impact the sorts of insects involved and the SPs. Additionally, the occurrence of chemicals influenced the decay rate and the attractiveness of insects to carcasses.

\section{Fayoum}

The effect of tramadol on rat carcass decomposition, SPs, and rate of growth of Sarcophaga argyrostoma Robineau-Desvoidy was investigated in a study by AbouZied (2016). According to the research, the decomposition of the treated carcass was not substantially quicker than that of control carcasses. Chrysomya albiceps, L. cuprina, and M. domestica were fewer in treated carcasses than control carcasses. Female Sarcophaga spp., in contrast, were more drawn to the treated ones. Sarcophaga argyrostoma maggots collected from treated groups were much longer than that collected from control groups, and maggots fed treated groups pupated 2 days later than maggots fed control groups. As a result, tramadol had no effect on carcass decay, but it did affect the insect appeal to carcasses.

\section{Qena}

Aly et al. (2017) did a research in Qena that looked at the insects that were associated to rabbit carcasses in both outdoor and indoor settings. They found that, in comparison to winter and fall, the rate of body decomposition was quicker in summer and spring. Outdoor bodies decay more quickly than indoor bodies. Outdoor bodies decay more quickly than indoor bodies. There was a total of 18 species identified, including 5 in the outdoors, 3 in the indoors, and 10 common species among them. Twelve Diptera, three Coleoptera, and three Hymenoptera species were reported. Blowflies and flesh flies were also the earliest to appear on rabbit carcasses. According to the authors, variations 
in decomposing stages, place, and seasonality impacted insect types and succession tendencies.

\begin{abstract}
Assiut
Abd El-Aziz and El Shehaby (2019) analyzed the forensic arthropod species that colonizes rat carrions in an aerated habitat throughout the spring season. Consequently, the fauna consists of 13 species of insects from 10 families, with blowflies being the first to arrive, followed by other flies in various stages of decay, and beetles limited to the late stages. Finally, the date of the initial insect appearance and the insect type varies depending on the decay stage.
\end{abstract}

\section{Giza}

The effects of clothes on the decomposition and insect attractiveness to rabbit carcasses were investigated by AbouZied et al. (2020). They discovered that clothes considerably slowed the decay rate and that the existence of clothes had no impact on the insect species drawn to the carcass or the SPs recorded.

\section{Sharqia}

During the summer season, Farag et al. (2021) looked at the variety and SPs of insects that colonized indoor rat carrion killed by various methods (cervical displacement, electrocution, immersion, or slaughtering). The most prevalent insects discovered were flies and beetles, with blowflies being the first to occupy the carrion and lasting until the start of the dry stage. In addition, neither the SPs nor the number of related insects varied between the control and immersion groups. There was, however, a distinction between the electrocuted and slaughtered groups.

\section{Insect growth and development studies}

It is crucial to know which insects are attracted to dead bodies in a specific region, as well as the growth rates of prominent carrion insect larvae, when estimating PMI using insect data (Gennard 2007). According to Tarone and Benoit (2019), the location temperature data is critical for complete entomological investigation since insects have temperature-dependent life cycles. Still, temperature is the extremely considerable piece of data applied to PMI estimation based on the growth rates of insects, as per Byrd and Sutton (2020).

Nine developmental experiments were brought in six governorates, focusing on five flies: four blowflies and one flesh fly. El-Shazly et al. (1995) compared the developing and propagative characteristics of Ch. albiceps and Parasarcophaga argyrostoma, then age-specific survival and productiveness. They noticed that the two flies are on opposite ends of the r-strategist spectrum. Kheirallah et al. $(2006,2007)$ investigated the temperature effects on the growth of Lucilia sericata Meigen and Ch. albiceps using four different temperatures. According to the studies, Ch. albiceps has a greater growth level and a longer larval development time than L. sericata. Moreover, it was discovered that in pure and mixed cultures of varied densities, Ch. albiceps development was unaffected when L. sericata density grew while Ch. albiceps density stayed constant. Likewise, the sex ratio of both species developing in pure and mixed cultures was unaffected by egg density or temperature, and greater extents resulted in lower adult sizes for both species.

Rashed et al. (2015) used Ch. albiceps to probe the impact of temperature changes on growth rate in distinct seasons. They observed that the total development period of the blowflies was affected by temperature fluctuations and showed substantial seasonal variability. High temperatures promote the growth of the fly, but low temperatures slow it down. Females emerged at higher rates than males, and the female ratio was greater throughout the winter. Abd El-Gawad et al. (2018) also looked at how the rodenticide warfarin influenced the growth and survival of fly maggots (L. sericata, Ch. albiceps, and Ch. megacephala). They discovered that treated larvae grew faster than control larvae, and seasonal temperature fluctuation is a crucial element in the blowflies' growth time.

Gabre et al. (2005) investigated the Ch. megacephala life cycle in the lab at a temperature of $26^{\circ} \mathrm{C}$, where the two-sex life table assessment offers a thorough explanation of the fly developmental stage differentiation. Ibrahim et al. (2014) also investigated the effect of larval density on the fly population ecology and survival. They observed that there is a link between larval density and survival, that density affects pre-oviposition time but not sex ratio, and that density influences fertility.

AbouZied et al. (2003) used an age-stage, two-sex life table, and different growth rates among individuals to evaluate raw data on L. cuprina life history in a lab setting. The outcomes showed that the L. cuprina population is r-strategist. Also, Elshehaby et al. (2016) looked at the impacts of three various types of feed (liver, beef, and meat) on the number of $L$. sericata and their growth time. They determined that the development rate of all stages of cultured flies increases when the kind of meat diet changes, flies prefer meat other than liver and beef, and the development characteristics of $L$. sericata were substantially higher with diet meat than with the other diets examined. As a result, the authors concluded that diet meat may be used to mass rear blowfly larvae for a variety of fundamental and applied research projects.

According to the developmental research, temperature is the most essential element influencing the flies' 
life cycle, with a substantial influence on pre-oviposition and incubation periods, egg hatching percentage, female fecundity, and larval growth time.

\section{Insect identification}

The precise and rapid classification of insects is a first and essential stage in using insect proof in forensics. According to Tang et al. (2012), traditional morphological insect identification poses a considerable challenge for forensic scientists, but genetic approaches for insect identification are faster and more efficient.

In Egypt, Tantawi and El-Kady (1997) used morphological methods to distinguish third-instar larvae of various flies from blowflies, flesh flies, and house flies, while Sawaby et al. (2016) identified 29 species from 9 families in a taxonomic study on beetles, and Sawaby et al. (2018) used the same characteristics to identify dipterous species.

A few articles, instead, used molecular identification, such as in a master research by El-Hefnawy (2013), data assessment utilizing the RAPD polymerase chain reaction technology proved the third larval instar of Sarcophaga carnaria Linnaeus. Aly (2014), Salem et al. (2015), and Abdel Ghaffar et al. (2018) also used short and long cytochrome oxidase I gene segments (COI) to distinguish between flies.

Furthermore, Elleboudy et al. (2016) used a new method called focus stacking to identify 76 Chrysomya species in Egypt, with Ch. albiceps and Ch. megacephala being the most common species. El-Hefnawy et al. (2020) explored the possible function of genome size measurements in forensics by using flow cytometry to explain the importance and ease of use of genome size estimates in flies (Wohlfahrtia magnifica Schiner and S. argyrostoma) obtained from Aswan and Benha. The study found variations in genome size within and between the juvenile stages of the two species. Finally, the forensic insects were identified using both morphological and molecular methods in the classification experiments.

\section{Entomotoxicology}

Entomotoxicology is commonly applied when toxicological tests on bodily tissues are not possible (Verma \& Paul, 2013), or when internal organs, blood, or urine are not available for a criminal probe, entomotoxicology is frequently used (Sankhla et al., 2017). Several studies in Egypt employed it to detect the existence of chemicals in insect larvae and body tissues, as well as their effects on larval growth.

Tantawi et al. (2001) utilized a radioimmunoassay technique to measure the level of morphine in the 3rd instar larvae of blowflies and flesh flies attracted to rabbit carcasses left outdoors. El-Samad et al. (2011) employed high-performing liquid chromatography with a UV-visible spectrophotometric detector to identify tramadol in rabbit blood and tissues, along with fly larvae, to assess tramadol's impact on the growth of $L$. sericata larvae. According to the research, tramadol concentrations in larvae were much lower than those detected in tissues, treated rabbits reached maximum size faster than control rabbits, and the overall developing period rose significantly when the first administered dose was increased.

Malathion was noticed in Ch. albiceps maggots and tissues of treated dog carcasses in a research by Fouda et al. (2017a), where it dramatically changed the durations of developing stages of flies inhabiting the treated carcass but had no effect on the insect number drawn to the carcasses. Fouda et al. (2017b) were also capable to detect ephedrine in Ch. albiceps larvae, and the influence of ephedrine on the growth of maggots. In addition, Tahoun and Abouzied (2017) used GC-Ms analysis to detect tramadol in S. argyrostoma maggots and investigate the influence of tramadol accumulation on maggots and pupae development rates. They observed that tramadol accumulation decreased the maggots and pupae lifespans. When maggots were fed tramadol-treated livers, the average weight of the 3rd instar larvae decreased while the pupae weight rose.

Bakr et al. (2018) looked at the impact of malathion on Ch. megacephala larval development, and the consequences for PMI estimation. Malathion was detected in all treated rabbit tissues, but not in the controls, it was detected in the lungs in the highest intensities, followed by muscle tissue and lipids, as well as in all 3rd larval instars and pupae.

The impacts of morphine on the growth in four flies, $L$. sericata, Ch. albiceps, Ch. megacephala, and S. argyrostoma, were studied by El-Samad et al. (2020). The drug was found in both blood and samples of tissue taken from treated rabbits, albeit the amounts of morphine found in larval samples for all fly species were lower than in rabbit tissues. Abd El-Gawad et al. (2020) looked at the possibility of using fly larvae as diagnostic indicators for warfarin toxicity. Maggots exhibited two distinct results: positive, which may be owing to the larvae eating on the rabbit liver, and negative, which could be owing to the toxin being highly destroyed after 18 hours of ingestion.

In general, forensic entomotoxicology was applied by numerous Egyptian researchers to check for drugs like tramadol, malathion, morphine, ephedrine, and warfarin in insect larvae and carcass tissues.

\section{Biochemical studies}

Biochemistry is the analysis of biological processes at the cellular and molecular level using chemicals. Sawaby et al. (2009) conducted the only study in Egypt to explore 
how the pesticide pirimiphos-methyl changes the protein composition of insects drawn to treated rabbit carrion, with the insecticide's effect on insects. According to the research results, Ch. albiceps and Dermestis maculatus DeGeer contain a functional esterase system. The value of entomological techniques for detecting pharmaceuticals in insects that infested drug-death suspect carcasses, for instance protein profiles and esterase assays, which are involved in physiological and endogenous metabolic processes, is highlighted in this work.

\section{Electrophysiology}

Electrophysiology is a subfield of physiology that studies the electrical properties of biological cells and tissues. There have been several probes of chemosensory sensilla in a variety of insect families, but there is comparatively little information about forensic fly species. Refai et al. (2009) investigated the electrical reactions of receptor nerve cell on the antennae, labium, and tarsus of Calliphora vicina Robineau-Desvoidy to various quantities of morphine in decaying tissues alongside odors originating from under the surface. The 5th cell "deterrent cell" was shown to be the best responsive cell to morphine sulfate at all sites of stimulation, although with varying levels of sensitivity. These findings clearly imply that varying dosages of morphine sulfate have a great repellant impact on C. vicina attraction. Also, to investigate if morphine sulfate has a repellant impact on blowfly attraction to corpses, Abdel Ghaffar et al. (2012) conducted electrophysiological and behavioral studies. They realized that the drug stimulated the fifth cell in the chemosensillae, causing a delay in blowfly attraction to treated carrions compared to control carrions. Researchers concluded that entomologists must be conscious of the delay in adult fly arrival to the carrion in cases where the victim died because of morphine abuse, which could lead to a misinterpretation of PMI estimation, especially when previous studies were showed on morphine-free experimental carcasses.

\section{Human case study}

Forensic entomology, according to Hall (1990), concentrates on insect-infested human cadavers. Insects may represent crucial tools in criminal investigations, in addition to their biological significance (Catts, 1992). Insects can be designed to estimate the time since death, especially in the case of putrefied corpses (Singh, A. et al. 2019). Insects can also aid when typical PMI estimation methods based on early postmortem phenomena like body cooling, livor mortis, and rigor mortis fail (Saukko \& Knight, 2004). Several experts have studied the insects that are drawn to human remains in different countries (Lee, 1989; Barreto et al., 2002; Lira et al., 2020, Mashaly et al., 2020). Also, no insect attraction to human cases has been studied in the regions around Egypt, except for Saudi Arabia (Al-Qahtni et al., 2019, 2020). In Egypt, a few studies on human cases were done to document the drawn insects to the bodies and attempt to apply this knowledge in estimating the PMI.

Galal et al. (2009) investigated the insect fauna and SPs on degraded human leftover parts in Assiut during the summer and spring. Flesh flies, blowflies, house flies, skin beetles, and ants were all found, with flies being the highly frequent insects and $\mathrm{Ch}$. albiceps being the extremely prevalent species. Moreover, El-Mehy et al. (2015) investigated the ability of insects to estimate PMI in 15 human cases in Gharbia (11 men and 4 females). Nine cases were found in open habitats, three in aquatic environments, and three in subterranean habitats, with ages ranging from 7 to 50 years. In the 15 carcasses, blowflies and flesh fly maggots were found, with $\mathrm{Ch}$. albiceps being the most common (9 instances) and Sarcophaga species following closely behind (4 cases). In two cases killed by carbamate and organophosphorus poisoning, toxicological investigations using larvae attached to decaying remains were helpful. Besides, Tantawi et al. (2018) collected insects during an autopsy of 15 human bodies at El-Esaaf Mortuary in Kom El-Deka, Alexandria. Six fly species maggots from three families were gathered from the remains, as these flies were the first to occupy the remains and hence are crucial in PMI estimating in Alexandria. Blowfly maggots were the highly frequent and numerous insects in all times and environments, with Ch. albiceps being the extremely common species; however, in warmer seasons, S. argyrostoma was revealed to be a very indicative species.

Three studies on human cases were conducted in Egypt, in three distinct governorates, to recording the drawn insects to the dead corpses and PMI estimation.

\section{Forensically important insects in Egypt}

From the 55 studies in Egypt, twenty insect species (Table 2) belonging to 3 orders were selected as the most significant and common species. There were 11 fly species, including 5 Calliphorids, 4 Sarcophagids, and 2 Muscids. The order Coleoptera had four species, two Dermestids, one Histerid, and one Clerid, whereas the order Hymenoptera included five Formicides. Among the 20 common species analyzed, Ch. albiceps, Ch. megacephala, L. sericata, M. domestica, and D. maculatus were the leading species of corpses community structure. Chrysomya albiceps was the highly often introduced species in 11 governorates and 35 articles, followed by $L$. sericata verified in 7 governorates and 21 articles, and Ch. megacephala introduced in 6 governorates and 18 articles. From Muscidae, $M$. domestica was introduced in 







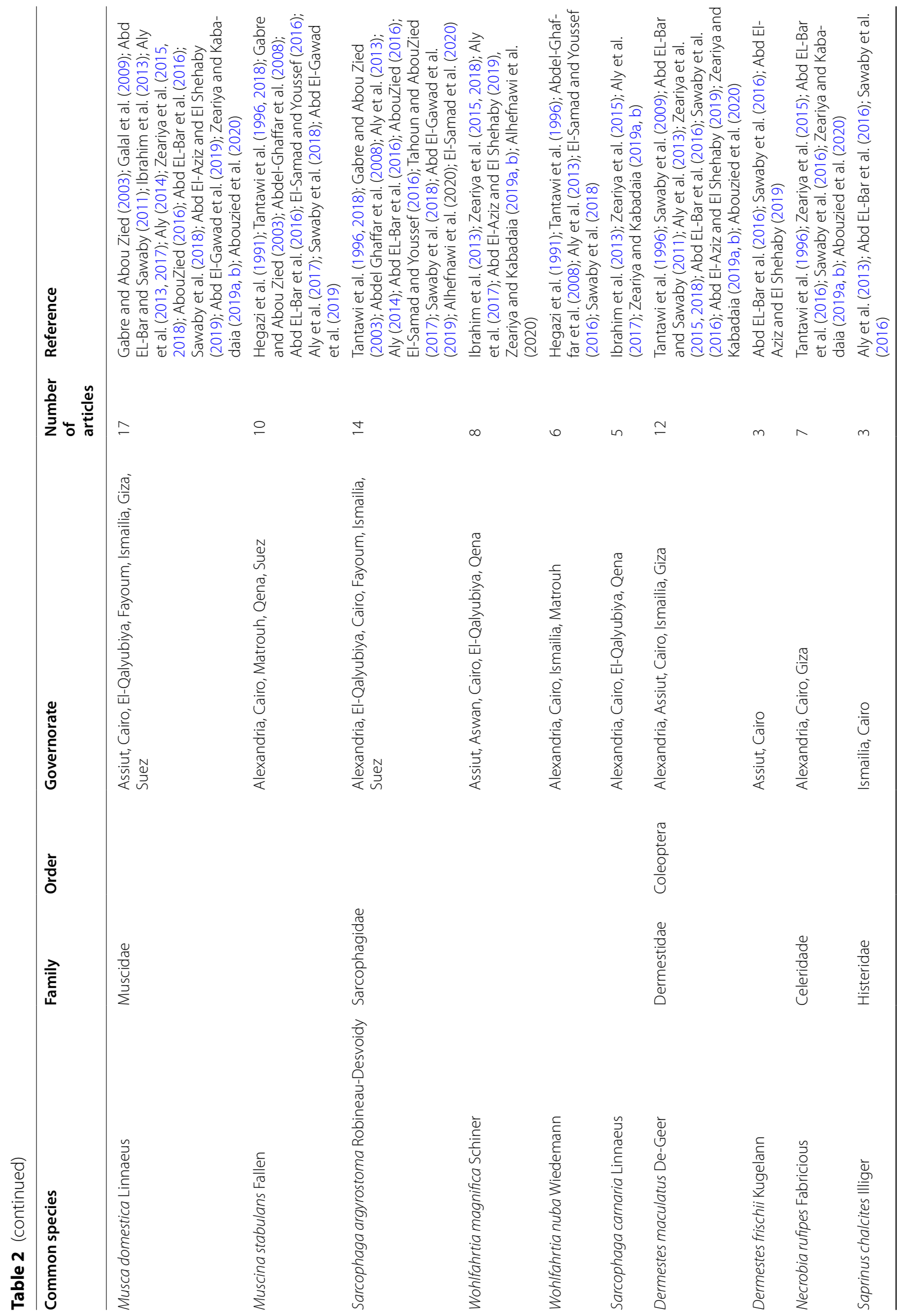




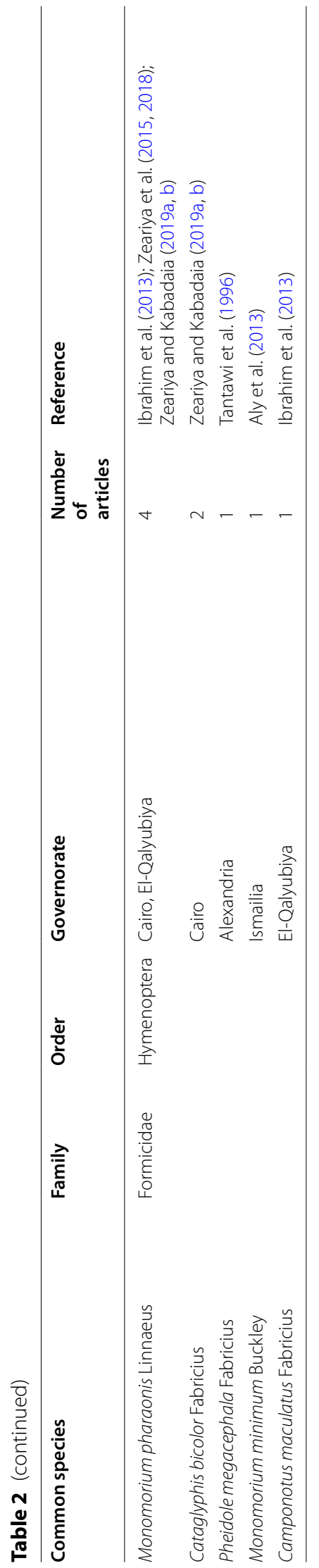


7 governorates and 17 articles, while $S$. argyrostoma was found in 14 articles and 6 governorates. In 5 governorates and 12 articles, $D$. maculatus was the most frequent beetle, whereas Monomorium pharaonis Linnaeus from ants was observed in 2 governorates and 4 articles. According to the articles, Cairo had 17 species, Alexandria had 11 species, and Ismailia had 9 species among Egypt's 20 most frequent species. Suez and El-Qalyubiya had 8 species each, while Giza and Assiut had 6 species each. Moreover, Qena contained 5 species and Fayoum and Matrouh had 4 species each. Finally, Gharbia had two species, but Sharqia only had one species, Ch. albiceps. In general, 20 insect species were identified as frequent in the research, with 5 being named the most frequent, and Ch. albiceps looks to be the common insect in all locations.

\section{Animals used in the research}

According to Catts and Goff (1992), the animal model must closely resemble the pattern of human body decomposition, be reasonably easy to get, be affordable, and not generate public outcry. One area where the legality of baseline data obtained through decomposition research is commonly questioned is the sort of non-human model used. Various animal models were used in experiments of arthropod SPs on decomposing carcasses, including lizards (Cornaby, 1974); elephants (Coe, 1978); sheep (Fuller, 1934); dogs (Boulkenafet et al., 2015); domestic cats (Early \& Goff, 1986); fishes and pigeons (Omer, 2014); camel, goat, and pigs (Tabor et al., 2005); dogs (Mashaly et al., 2019); and rabbits (Al-Mesbah et al. (2012); Mashaly et al. (2017).

In Egypt, several animals were used in the investigations, with the rabbit being the most used animal in 30 of them, followed by rats in three. Each of the animals, including the fish, guinea pig, and dog, took part in only one research. Three experiments used rabbits and dogs as comparative animals, while two others used rabbits and guinea pigs. Additionally, rabbits and rats were utilized in one research, while mature snail meat and a small carp were used in another.

\section{Review articles published by Egyptian scientists}

A review article can support to know the level of research, address evident contradictions, uncover research gaps, and even build consensus where none previously existed. Several Egyptian scholars produced review articles in the field of FE. El-Kady (1999) wrote an article concerning the complications in using FE, in which he discussed a number of topics, including animals as models for human corpses, replicated carcasses, way of death, nocturnal oviposition of flies, species identifications, maggot age estimation, and foreign chemicals as a cause of error. He concluded that such issues are among the methodological challenges that the entomology expert is likely to face when using insects to PMI estimation and that FE researchers must follow strict guidelines, in adding to develop a better considerate of the ecologies of species allied with decaying bodies. Likewise, Rasmy (2007) discusses how insects and acarines may give crucial information in homicide investigations, as well as a number of criminal cases, including the effective use of entomological data in murder investigations. Rasmy (2008) also made a brief statement about the use of mites and insects as proof of physical abuse. Then, Shalaby (2018) released a brief statement about the possibility of employing insects as witnesses to man's aggressive approaches in forensic research in Egypt. As well as FE definitions, history, carrion decomposition phases, and related arthropods, importance in resolving crimes, techniques for obtaining entomological proof at death sites, and research projects undertaken in Egypt were all addressed by Kenawy and Abdel-Hamid (2019). Ultimately, El-Bassiony (2020) identified a range of blowfly SPs on Egyptian mammalian carrions. It also examined at how regional weather situations influenced the life cycle of $L$. cuprina, a common fly that survives in cadavers after death.

In general, six review papers were published in Egypt, attempting to cover the major issues of the FE, the difficulties in applying the field, and various data about common insects.

\section{Discussion}

The topic of FE is constantly developing, and developmental and distribution data on key species are still understudied in this field, even though it has been in use for a long time. Although the number of academic articles issued in the field of $\mathrm{FE}$, as well as the number of individuals who practice it, more study is needed to find answers to unsolved issues.

In Egypt, FE's importance in the present scientific community is rising, with 7 articles published between 1990 and 1999, 11 papers published between 2000 and 2010, and 37 papers issued between 2011 and 2021. The study appeared that FE researchers in Egypt were interested in the research of seasonal SPs, entomotoxicology, and insect development. Other aspects of FE, for example, a lack of study in several governorates, aquatic and coastal habitats, the impact of different variables such as burning and burial, human cadaver studies, and additional studies on beetles and ants, are also missing. Although FE research using a molecular approach began in the prior decade, it has failed to make significant progress in 
Egypt. Furthermore, most of the experiments have been conducted on blowflies and flesh flies, with very little on house flies. Because Ch. albiceps is the highly reported species in Egypt's studies, it deserves special attention.

\section{Suggestions}

Egyptian academics should pay a larger focus on FE studies in the future. Still, an Egyptian Society for FE should be created to facilitate communication and collaboration among Egyptian scientists.

\section{Conclusions}

This review's purpose is to create a general overview of Egyptian FE. In Egypt, 55 studies were carried out over 12 governorates. Insect SPs, developmental and toxicological studies, and insect identification were all studied using an assortment of animal models, with some human case studies. Likewise, the study showed a shortage of research in some governorates, with some essential components of FE work, like the impact of varied environmental conditions on corpse decay and SPs. There is also a need to interact with legal medicine to work on more human bodies, which will facilitate to expand FE in Egypt and open the way for its use in criminal probes.

\section{Abbreviations}

FE: Forensic entomology; SPs: Succession patterns; PMI: Postmortem interval.

\section{Acknowledgements}

Not applicable

\section{Authors' contributions}

The author of this text, Ashraf Mashaly, was a key contributor. Abdelwahab Ibrahim contributed to the writing of the final text and read and evaluated it. The final text was read and approved by the authors.

\section{Funding}

Not applicable

\section{Availability of data and materials}

All data used in this manuscript have been completely described in this article itself.

\section{Declarations}

Ethics approval and consent to participate

Not applicable

\section{Consent for publication}

Not applicable

\section{Competing interests}

The authors declare that they have no competing interests.

\section{Author details}

${ }^{1}$ Department of Zoology, Faculty of Science, Minia University, El Minia 61519 , Egypt. ${ }^{2}$ Department of Entomology, Faculty of Science, Benha University, Benha, Egypt.
Received: 24 August 2021 Accepted: 25 January 2022

Published online: 07 February 2022

\section{References}

Abd El-Aziz FEA, El Shehaby DM (2019) Effect of arthropods on the decomposition of rat carrions in an aerated environment in spring season in Assiut, Egypt. Egypt Acad J Biolog Sci 11(1):1-12.

Abd EL-Bar MM, Sawaby RF (2011) A preliminary investigation of insect colonization and succession on remains of rabbits treated with an organophosphate insecticide in El-Qalyubiya Governorate of Egypt. Forensic Sci Int 208:e26-e30

Abd EL-Bar MM, Sawaby RF, EL-Hamouly H, Hamdy R (2016) A preliminary identification of insect successive wave in Egypt on control and zinc phosphide-intoxicated animals in different seasons. Egy J Forensic Sci 6:223-234

Abd El-Gawad A, Badawy RM, Abd El-Bar MM, Kenawy MA (2019) Successive waves of dipteran flies attracted to warfarin-intoxicated rabbit carcasses in Cairo. Egypt. J Basic Appl Zool 80:56

Abd El-Gawad A, Kenawy MA, Badawy RM, Abd El-Bar M (2018) Effect of intoxication with warfarin rodenticide on development and survival of forensically important fly maggots in Egypt. Egypt. Acad J Biolog Sci 10:1-10

Abd El-Gawad A, Kenawy MA, Badawy RM, Abd El-Bar MM (2020) Fly maggots as bio-indicators of warfarin poisoning in rabbits as an animal model. Egypt. Acad J Biolog Sci 12(2):43-48

Abdel Ghaffar HA, Goff ML, Shalaby OA (2008) Seasonal field variations of arthropod development and succession on exposed rabbit carcasses induced by propoxur in a semi desert region in Egypt. J Egypt Ger Soc Zool 56E:91-119

Abdel Ghaffar HA, Moftah MZ, Favereaux A, Swidan M, Shalaby O, El Ramah S, Gamal R (2018) Mitochondrial DNA-based identification of developmental stages and empty puparia of forensically important flies (Diptera) in Egypt. J Forensic Sci Med 4(3):129-134

Abdel Ghaffar HA, Tantawi T, Gaboub I, Shalaby OA, El-Refai N (2012) Forensically flies detect the nutritional value of corpses through neuro-chemoreceptive cells-(5TH CELL). Am J Neurosci 3(2):63-70

AbouZied EM (2016) Postmortem attraction of sarcosaprophagous diptera to tramadol-treated rats and morphometric aspects of the developed larvae. Neotrop Entomol 45(3):326-332

Abouzied EM, Al-Sahhaf ZY, Hiji AM (2020) The influence of winter weather and clothes on the decomposition of rabbit carcasses and insect succession, in urbanized district of 6th October city. Egypt. Int J Entomol Res 5(6):31-39

Abouzied EM, Gabre RG, Hsin Chi H (2003) Life table of the Australian sheep blow fly Lucilia cuprina (Wiedemann) (Diptera: Calliphoridae). Egypt J Zool 41:29-45

Al-Mesbah H, Moffatt C, El-Azazy OME, Majeed QAH (2012) The decomposition of rabbit carcasses and associated necrophagous Diptera in Kuwait. Forensic Sci Int 217:27-31

Al-Qahtni AH, Al-Khalifa MS, Mashaly AM (2020) Two human cases associated with forensic insects in Riyadh, Saudi Arabia. Saudi J Biol Sci 27:881-886

Al-Qahtni AH, Mashaly AM, Alajmi RA, Alshehri AA, Al-Musawi ZM, Al-Khalifa MS (2019) Forensic insects attracted to human cadavers in a vehicular environment in Riyadh, Saudi Arabia. Saudi J Biol Sci 26:1499-1502

Aly MZY, Osman KSM, Galal FH, Ali GHM (2017) Comparative study on outdoor and indoor forensic insects encountered on rabbit corpses in Upper Egypt. J Pharm Biol Sci 12:41-54

Aly SM (2014) Reliability of long vs short COI markers in identification of forensically important flies. Croat Med J 55:19-26

Aly SM, Jifang W, Xiang W, Jifeng C, Qinlai L, Ming Z (2013) Identification of forensically important arthropods on exposed remains during summer season in Northeastern. Egypt. J Central South Uni (Medical Science) 38:1-6

Amendt J, Campobasso CP, Gaudry E, Reiter C, LeBlanc H, Hall MJR (2007) Best practice in forensic entomology - standards and guidelines. Int J Leg Med 121:90-104

Anderson GS (2001) Succession on carrion and its relationship to determining time of death. In: Byrd JH, Castner JL (eds) Forensic entomology: the utility of arthropods in legal investigations. CRC, Boca Raton, FL, pp $143-175$ 
Bakr RFA, Ramadan RH, Hussien SMA (2018) Detection of malathion in different stages of Chrysomaya megacephala and its implications for forensic entomology. Egypt Acad J Biolog Sci 10(2):103-111

Barreto M, Burbano ME, Barreto P (2002) Flies (Calliphoridae, Muscidae) and beetles (Silphidae) from human cadavers in Cali, Colombia. Mem'orias do Instituto Oswaldo Cruz 97(1):137-138

Boulkenafet F, Berchi S, Lambiase S (2015) Preliminary study of necrophagous Diptera succession on a dog carrion in Skikda, North-east of Algeria. J Entomol Zool Studies 3(5):364-369

Byrd J, Sutton L (2020) Forensic entomology for the investigator. WIREs Forensic Sci:e1370

Campobasso CP, Di Vella G, Introna F (2001) Factors affecting decomposition and diptera colonization. Forensic Sci Int 120:18-27

Campobasso CP, Introna F (2001) The forensic entomologist in the context of the forensic pathologist's role. Forensic Sci Int 120:132-139

Catts EP (1992) Problems in estimating the PM! in death investigations. J Agric Entomol 9(4):237-243

Catts EP, Goff ML (1992) Forensic entomology in criminal investigations. Annu Rev Entomol 37:253-272

Catts P, Haskell N (1990) Entomology and death a procedural Guide. Joyce's Print Shop, South Carolina

Coe M (1978) The decomposition of elephant carcasses in the Tsavo (East) National Park, Kenya. J Arid Environ 1:71-86

Cornaby BW (1974) Carrion reduction by animals in contrasting tropical habitats. Biotropica 6:51-63

Early M, Goff ML (1986) Arthropod succession patterns in exposed carrion on the island of O'ahu, Hawaiian Islands, USA. J Med Entomol 23:520-531

El-Bassiony GM (2020) Blowflies (Diptera: Calliphoridae) as forensic indicators in Egypt with special reference to the development data of Lucilia Cuprina (Wiedemann). Sumerianz I Biotechnol 3(7):43-51

El-Hefnawy AA (2013) Comparative study on the estimation of postmortem interval using insect molecular genetics, M.Sc. thesis of Benha University

El-Hefnawy AA, Abul Dahab FF, Ibrahim AA, Salama EM, Mahmoud SH, Johnton JS, Tarone AM (2020) Genome size variation for some forensically important Sacophagidae in Egypt. Benha J Appl Sci 5(1):19-24

El-Kady EM (1999) Problems facing application of forensic entomology. Pak J Biol Sci 2(2):280-289

El-Kady EM, Abd El-Ghaffar H, Tantawi TI (1994a) A checklist of arthropods associated with exposed rabbit carrion in Alexandria district, Egypt. J Egy Ger Soc Zool 14(D):181-193

EL-Kady EM, YEE E, Shalaby OA (1994b) Variations in the blow and flesh flies succession on rabbit carrions killed by different methods. J Egypt Ger Soc Zool 13:451-489

Elleboudy NA, Ezz Eldin HM, Azab SMS (2016) Focus stacking technique in identification of forensically important Chrysomya species (Diptera: Calliphoridae). Egypt J Forensic Sci 6(3):235-239

El-Mehy I, Sief A, Soliman E, Hassan NA, Alrouf TA (2015) Application of entomology in some medicolegal issues. Austin J Forensic Sci Criminol 2:1036

El-Samad LM, El-Moaty ZA, Makemer HM (2011) Effects of Tramadol on the development of Lucilia sericata (Diptera: Calliphoridae) and detection of the drug concentration in postmortem rabbit tissues and larvae. J Entomol 8(4):353-364

El-Samad LM, Tantawi TI, El-Ghaffar HA, Beltagy Bl, El-Abd E (2020) The effect of morphine on the development rate of flies (Diptera: Calliphoridae, Sarcophagidae) reared on rabbit carcasses containing this drug and its implications to postmortem interval estimates. Swed J BioSci Res 1(1):28-38

El-Samad LM, Youssef MH (2016) Seasonality of insect succession on remains of rabbits treated with amitriptyline (antidepressant drug) in Alexandria. Egypt. J Adv Biol 9(1):1783-1798

El-Shazly MM, El-Sherif HA, Omar AH (1995) A comparative study on the reproductive strategies of a larviparous and an oviparous fly associated with carrion. J Swiss Entomol Soc 68:323-330

Elshehaby M, Tony M, Sultan A, Abdel-baset A-RMA (2016) Laboratory colonization of Lucilia sericata (Meigen) (Diptera: Calliphoridae) strain from Assiut. Egypt. J Entomol Zool Studies 4(5):875-880

Farag MR, Anter RGA, Elhady WM et al (2021) Diversity, succession pattern and colonization of forensic entomofauna on indoor rat carrions concerning the manner of death. Rend Fis Acc Lincei. https://doi.org/ 10.1007/s12210-021-01009-w

Fouda MA, Al-Dali AG, Hammad KM, Abdrabou MM, Kabadai MM (2017b) Detection and effect of ephedrine sulphate on the development rate of the forensic blow fly larvae Chrysomya albiceps (Diptera: Calliphoridae) colonize a dog carcass. Int J Adv Res Biol Sci 4:118-126

Fouda MA, Al-Dali AG, Hammad KM, Abdrabou MM, Kabadaia MM (2017a) Entomotoxicological study on the forensic blow flies Chrysomya albiceps associated with dog carcass. Egypt. Acad J Biolog Sci 10(6):107-121

Fuller ME (1934) The insect inhabitants of carrion: a study in animal ecology (Council for scientific and industrial research). Australia: CSIRO 82:1-62

Gabre RM (2002) Sarcosaprophagous flies in Suez province, Egypt. I-Seasonal distribution and sex-ratio. J Egypt Soc Parasitol 32(3):867-878

Gabre RM, Abou Zied EM (2003) Sarcosaprophagous flies in Suez province, Egypt. II- Synanthropic and abundance degrees. Bull Ent Soc Egypt 80:125-132

Gabre RM, Adham FK, Chi H (2005) Life table of Chrysomya megacephala (Fabricius) (Diptera: Calliphoridae). Acta Oecologica 27:179-183

Galal LAA, Abd-El-hameed SY, Attia RAH, Uonis DA (2009) An initial study on arthropod succession on exposed human tissues in Assiut. Egypt. Mansoura J Forensic Med Clin Toxicol XVII:55-74.

Gennard DE (2007) Forensic entomology: an introduction. John Wiley \& Sons, Chichester, UK

Goff ML (1993) Estimation of postmortem interval using arthropod development and successional patterns. Forensic Sci Rev 5:81-93

Grassberger M, Frank C (2004) Initial study of arthropod succession on pig carrion in a central European urban habitat. J Med Entomol 41:511-523

Hall RD (1990) Medico-criminal entomology. In: Catts EP, Haskell NH (eds) Entomology and death: a procedural guide, Joyce's Print Shop, Clemson (SC), pp 1-8

Hegazi EM, Shaaban MA, Sabry E (1991) Carrion insect of the Egyptian western desert. J Med Entomol 28:734-739

Henssge C, Madea B, Knight B, Nokes L, Krompecher T (1995) The estimation of the time since death in the early postmortem period. Arnold, London

Ibrahim AA, Galal FH, Seufi AM, El-hefnawy AA (2013) Insect succession associated with corpse's decomposition of the guinea pig Cavia porcellus in Benha City. Egypt. Acad J Biolog Sci 5:1-20

Ibrahim AA, Kamel AS, Helmy MN, Marwan DA (2014) Influence of larval density on some biological and demographic aspects of Chrysomya megacephala (Diptera: Calliphoridae). Egypt Acad J Biolog Sci A. Entomol 7(2):36-49

Kenawy MA, Abdel-Hamid YM (2019) Medico-legal forensic entomology "use of insects in death investigations" - a review. Egypt Acad J Biolog Sci 11(2):59-47

Kheirallah AM, Tantawi TI, Aly AH, El-Moaty ZA (2006) Effect of temperature on the development of Lucilia sericata (Meigen) and Chrysomya albiceps (Wiedemann) (Diptera: Calliphoridae) from Alexandria. Egypt. Environtropica 3(1 \& 2):53-61

Kheirallah AM, Tantawi Tl, Aly AH, El-Moaty ZA (2007) Competitive interaction between larvae of Lucilia sericata (Meigen) and Chrysomya albiceps (Wiedemann) (Diptera: Calliphoridae). Pakistan J Biol Sci 10(7):1001-1010

Lee HL (1989) Recovery of forensically important entomological specimens from human cadavers in Malaysia—an update. Malaysian J Pathol 11:33-36

Lira LA, Barros-Cordeiro KB, Figueiredo B, Galvão MF, Frizzas MR (2020) The carrion beetle Oxelytrum discicolle (Coleoptera: Silphidae) and the estimative of the minimum post-mortem interval in a forensic case in Brasilia. Brazil. Rev Bras Entomol 64(1):e201992

Lord WD, Rodriguez WC (1989) Forensic entomology: the use of insects in the investigation of homicide and untimely death. Prosecutor 22(3):41-48

Mashaly A, Alajmi R, Mustafa AE, Rady A, Alkhedir H (2017) Species abundance and identification of forensically important flies of Saudi Arabia by DNA barcoding. J Med Entomol 54:837-843

Mashaly A, Al-Khalifa M, Al-Qahtni A, Alshehri A (2020) Analysis of insects colonised on human corpses during autopsy in Riyadh. Saudi Arabia. Entomol Res 50(7):351-360

Mashaly AM, Al-Ajmi RA, Rady A, Al-Musawi Z, Farrukh A (2019) Species richness of scavenger insects on different carcass types. Tropical Biomedicine 36(3):630-639 
Morris B, Dadour IR (2015) Forensic entomology: the use of insects in legal cases. Law Book Company, Sydney

Nuorteva P, Nuorteva S (1982) The fate of mercury in sarcosaprophagous flies and in insects eating them. Ambio 11:34-37

Omer SSA (2014) The succession of forensic beetles on exposed and wrapped carcasses during winter and summer in Khartoum state. Master thesis. University of Khartoum, Sudan

Rashed SS, Yamany AS, El-Basheir ZM, Zaher EE (2015) Influence of fluctuated room conditions on the development of the forensically important Chrysomya albiceps (Wiedemann) (Diptera: Calliphoridae). Br J Med Med Res 5(11):1413-1421

Rasmy AH (2007) Insects and death: an overview on forensic entomology/ acarology. The First international conference of the Arab Society for Forensic Sciences and Forensic Medicine, Riyadh, Sausi Arabia, 12-14 November 2007.

Rasmy AH (2008) Mites and insects as indicators of physical abuse. J Egyptian Soc Acarol 2:1-2

Refai N, Shalaby OA, Tantawi TI, Gaaboub I and Ghaffar H (2009) Electrophysiological responses of Chemoreceptor neurons in Calliphora vicina (Diptera: Calliphoridae) to morphine sulfate and its implications in forensic entomology. Front. Neurosci. Conference Abstract: 3rd Mediterranean Conference of Neuroscience. doi: https://doi.org/10.3389/conf.neuro. 01.2009.16.135

Salem AM, Adham FK, Picard CJ (2015) Survey of the genetic diversity of forensically important Chrysomya (Diptera: Calliphoridae) from Egypt. J Med Entomol 52(3):320-328

Sankhla MP, Sharma K, Kumar R (2017) Future trends in forensic entomotoxicology. Int J Innov Res Sci Eng Technol 6(4):5584-5590

Saukko PJ, Knight B (2004) Knight's forensic pathology, 3rd edn. Distributed in the US by Oxford University Press, Arnold, London, UK

Sawaby RF, Abd El-Bar MM, El-Bermawy SM (2009) Biochemical studies of two forensically important insects in Egypt which had colonized rabbit carrions treated with organophosphorus compound. Egypt. Acad J biolog Sci 1(1):5-11

Sawaby RF, EL Hamouly H, Abo-El Ela RH (2016) Taxonomic study of the main families of Egyptian Coleoptera with forensic importance. Life Sci J 13(4):39-53

Sawaby RF, El Hamouly H, Abo-El Ela RH (2018) Diagnosis and keys of the main dipterous families and species collected from rabbit and guinea pig carcasses in Cairo. Egypt. J Basic Appl Zool 79:10

Shalaby OA (2018) Insects as witness to man's violent strategies: application to forensic science in Egypt. RRJOB 6(1):14-16

Singh A, Joshi A, Sankhla MS, Parihar K, Kumar R, Shiv K (2019) Determining time of death using forensic entomology. Int Medico-Legal Reporter J 2(3):7-13

Smith KGV (1986) A manual of forensic entomology. The Trustees of the British Museum (Natural History). United Kingdom, London

Sukontason K, Narongchai P, Kanchai C, Vichairat K, Sribanditmongkol P, Bhoopat T et al (2007) Forensic entomology cases in Thailand: a review of cases from 2000 to 2006. Parasitol Res 101:1417-1423

Tabor KL, Fell RD, Brewster CC (2005) Insect fauna visiting carrion in southwest Virginia. Forensic Sci Int 150:73-80

Tahoun IF, Abouzied EM (2017) The effect of the tramadol accumulated in rat liver on the development of the immature stages of the flesh fly Sarcophaga argyrostoma (Robineau-Desvoidy, 1830) (Diptera: Sarcophagidae). J Egypt Soc Parasitol 47(1):55-64

Tang ZC, Guo YD, Zhang XW, Shi J, Yang KT, Li XL, Chen YQ, Cai JF (2012) Identification of the forensically important beetles Nicrophorus japonicus, Ptomascopus plagiatus and Silpha carinata (Coleoptera: Silphidae) based on 16S rRNA gene in China. Trop Biomed 29:493-498

Tantawi TI, Abd El-Salam HF, Madkour SA (2001) Determination of drug levels in third instar larvae of flies (Diptera: Sarcophagidae, Calliphoridae) infesting outdoor-exposed rabbit carcass containing morphine in Alexandria, Egypt, using radioimmunoassay technique. Egypt. J. Forensic Sci. Applied Toxicol 1:52-64

Tantawi TI, El-Kady EM (1997) Identification of third instar larvae of forensically important flies (Diptera: Calliphoridae, Sarcophagidae and Muscidae) in Alexandria. Egypt. J Egypt Ger Soc Zool 23(E):1-20

Tantawi TI, El-Kady EM, Greenerg G, El-Ghaffar H (1996) Arthropod succession on exposed rabbit carrion in Alexandria. Egypt. J Med Entomol 33:566-580
Tantawi TI, El-Shenawy IE, Abd El-Salam HF, Madkour SA, Nevine M. Mahany NM (2018) Flies (Diptera: Calliphoridae, Sarcophagidae, Muscidae) associated with human corpses in Alexandria, Egypt. J BioSci Appl Res 4(2): 106-130

Tantawi TI, Wells JD, Greenberg B, El-Kady EM (1998) Fly larvae (Diptera: Calliphoridae, Sarcophagidae, Muscidae) succession in rabbit carrion: variation observed in carcasses exposed at the same time and in the same place. J Egy Ger Soc Zool 25:195-208

Tarone AM, Benoit J (2019) Insect development as it relates to forensic entomology. In: Byrd JH, Tomberlin JK (eds) Forensic entomology: the utility of arthropods in legal investigations, 3rd edn. Taylor and Francis, Boca Raton, FL, pp 225-252

Verma K, Paul R (2013) Assessment of postmortem interval, (PMI) from forensic entomotoxicological studies of larvae and flies. Entomol Ornithol Herpetol 1(1):1-4

Voss SC, Cook DF, Dadour IR (2011) Decomposition and insect succession of clothed and unclothed carcasses in Western Australia. Forensic Sci Inter 211:67-75

Zeariya MG, Hammad KM, Fouda MA, Al-Dali AG, Kabadaia MM (2015) Forensic-insect succession and decomposition patterns of rabbit carcasses in different habitats. J Entomol Zool Studies 3:473-482

Zeariya MGM, Hammad KM, Kabadaia MM (2018) Entomofauna associated with certain animal carcasses as a human model in Cairo. Egypt. Egypt Acad J Biolog Sci 10:85-102

Zeariya MGM, Kabadaia MM (2019a) Seasonality of insect succession and dog carcass decomposition in different habitats. Egypt Acad J Biolog Sci 11(1):29-39

Zeariya MGM, Kabadaia MM (2019b) The abundance of forensic insects on dog and rabbit carcasses in different habitats and developmental stages of Chrysomya albiceps as a forensic indicator. Egypt Acad J Biolog Sci 11:41-49

Zhu GH, Xu XH, Yu XJ, Zhang Y, Wang JF (2007) Puparial case hydrocarbons of Chrysomya megacephala as an indicator of the postmortem interval. Forensic Sci Int 169:1-5

\section{Publisher's Note}

Springer Nature remains neutral with regard to jurisdictional claims in published maps and institutional affiliations.

\section{Submit your manuscript to a SpringerOpen ${ }^{\circ}$ journal and benefit from:}

- Convenient online submission

- Rigorous peer review

- Open access: articles freely available online

- High visibility within the field

- Retaining the copyright to your article

Submit your next manuscript at $\boldsymbol{\nabla}$ springeropen.com 